\title{
DJ-I as a potential biomarker for the development of biocompatible multiwalled carbon nanotubes
}

This article was published in the following Dove Press journal:

International Journal of Nanomedicine

3 November 2011

Number of times this article has been viewed

\author{
Hisao Haniu' \\ Tamotsu Tsukahara ${ }^{2}$ \\ Yoshikazu Matsuda ${ }^{3}$ \\ Yuki Usui ${ }^{4}$ \\ Kaoru Aoki ${ }^{5}$ \\ Masayuki Shimizu ${ }^{5}$ \\ Nobuhide Ogihara ${ }^{5}$ \\ Kazuo Hara ${ }^{5}$ \\ Seiji Takanashi ${ }^{5}$ \\ Masanori Okamoto 5 \\ Norio Ishigaki ${ }^{5}$ \\ Koichi Nakamura ${ }^{5}$ \\ Hiroyuki Kato ${ }^{5}$ \\ Naoto Saito ${ }^{6}$ \\ 'Institute of Carbon Science and \\ Technology, ${ }^{2}$ Department of \\ Integrative Physiology and Bio- \\ System Control, Shinshu University, \\ Matsumoto, Nagano, ${ }^{3} \mathrm{Clinical}$ \\ Pharmacology Educational Center, \\ Nihon Pharmaceutical University, \\ Ina-machi, Saitama, ${ }^{4}$ Research Center \\ for Exotic Nanocarbons, ${ }^{5}$ Department \\ of Orthopaedic Surgery, ${ }^{6}$ Department \\ of Applied Physical Therapy, Shinshu \\ University School of Health Sciences, \\ Shinshu University, Matsumoto, \\ Nagano, Japan
}

Correspondence: Hisao Haniu Institute of Carbon Science and Technology, Shinshu University, 3-I-I Asahi, Matsumoto, Nagano 390-862I, Japan

$\mathrm{Tel}+8 \mathrm{I} 263372659$

Fax +8I 263358844

Email hhaniu@shinshu-u.ac.jp
Background: In the present study, we investigated whether DJ-1 could serve as a biomarker for assessing the biocompatibility of multiwalled carbon nanotubes (MWCNTs), using the highly purified carbon nanotube, HTT2800.

Methods: Using Western blot analysis, we determined DJ-1 protein levels in two different types of cells (one capable and the other incapable of HTT2800 endocytosis). Using quantitative real-time polymerase chain reaction, we also investigated the ability of purified nanotubes to alter DJ-1 mRNA levels.

Results: We demonstrated that the DJ-1 protein concentration was reduced, regardless of the cytotoxic activity of intracellular HTT2800. Furthermore, HTT2800 decreased the DJ-1 mRNA levels in a dose-dependent manner. This decrease in DJ-1 mRNA levels was not observed in the case of Sumi black or cup-stacked carbon nanotubes.

Conclusion: These data indicate that modification of DJ-1 expression is caused by the cell response to MWCNTs. We conclude that DJ-1 is a promising candidate biomarker for the development of biocompatible MWCNTs.

Keywords: multiwalled carbon nanotubes, DJ-1 protein, Western blot, quantitative real-time polymerase chain reaction

\section{Introduction}

Carbon nanomaterial technology, including the development of $\mathrm{sp}^{2}$-based carbon nanotubes, has advanced greatly during the last 25 years. The nanoscale size and extraordinary physicochemical properties of multiwalled carbon nanotubes (MWCNTs) have proven very useful in a wide variety of applications, including nanocomposites, sensors, energy storage, energy-conversion systems, field-emission displays, radiation sources, medical applications, and other nanodevices. ${ }^{1,2}$ MWCNTs can be mass-produced by chemical vapor deposition methods, especially the floating reactant method. ${ }^{3}$ Simultaneously, occupational and public exposure to manufactured nanomaterials has increased significantly. Carbon materials boast high biocompatibility. However, because of their unique nanoscale size and high aspect ratio $(>100)$, MWCNTs, like asbestos, may present important human health hazards. ${ }^{4-7}$

The human body can be exposed to MWCNTs through five possible routes, ie, inhalation of airborne carbon nanotubes, dermal penetration by skin contact, injection of engineered MWCNTs, implantation of composite MWCNTs, and ingestion with drinking water or food additives. Once in the body, MWCNTs are thought to be biopersistent. ${ }^{8}$ Safety evaluations of MWCNTs have been performed using in vitro and in vivo models. ${ }^{9-12}$ However, there is no consensus as to whether or not MWCNTs 
affect the human body. Thus, it is important to identify biomarkers that clarify whether MWCNTs are taken into the system, regardless of their ultimate effect. Such biomarkers will also prove useful for the development of biocompatible MWCNTs.

DJ-1 protein, encoded by the PARK7 gene, belongs to the peptidase C56 family. It functions as a redox-sensitive chaperone (a sensor for oxidative stress), ultimately protecting neurons against oxidative stress and cell death. ${ }^{13-15}$ Moreover, it has proven to be a biomarker for Parkinson's disease and some types of cancer. ${ }^{16-18}$ Using a proteomic approach, we recently revealed that expression of this protein decreased when U937 cells were exposed to MWCNTs for 4 days. However, we did not detect biological responses, such as pathological or histological changes, by conventional methods. ${ }^{19,20}$

In the present study, we investigated whether DJ-1 could serve as a biomarker for biocompatible MWCNTs. We used the highly purified carbon nanotube, HTT2800, and two different types of cells (characterized by their contrasting biological responses to HTT2800).

\section{Methods}

\section{Carbon nanomaterials}

We used the highly purified MWCNT, known as HTT2800, described in detail previously. ${ }^{3}$ In brief, HTT2800 is characterized by a high aspect ratio, a diameter of $100-150 \mathrm{~nm}$, and length of $10-20 \mu \mathrm{m}$. The autoclave sterilization conditions were $121^{\circ} \mathrm{C}$ for 15 minutes. HTT2800 was dispersed with $0.1 \%$ gelatin (Nacalai Tesque, Kyoto, Japan) in phosphate-buffered saline and sonicated for 30 minutes. We used other carbon materials, ie, Sumi black (Unique Tattoos, Subiaco, Australia) 30-50 nm in particle size, and cup-stacked carbon nanotubes (GSI Creos, Tokyo, Japan) $100 \mathrm{~nm}$ in diameter and $0.5-20 \mu \mathrm{m}$ in length. These were autoclaved and dispersed in the same manner used for HTT2800.

\section{Cell culture}

The monoblastic human cell line, THP-1, and the human malignant pleural mesothelioma cell line, MESO-121, were purchased from Riken (Ibaraki, Japan). The cells were cultured in RPMI 1640 supplemented with $10 \%$ fetal bovine serum, at $37^{\circ} \mathrm{C}$ in a $5 \% \mathrm{CO}_{2}$ humidified incubator, and passaged twice a week. For each study, the cells were seeded at a density of $4 \times 10^{4}$ cells $/ \mathrm{mL}$ (THP- 1 ) and $2 \times 10^{4}$ cells $/ \mathrm{mL}$ (MESO-1). The MESO-1 cells were allowed to adhere for 24 hours.

\section{Alamar blue assay}

To determine the proliferation of cells exposed to different concentrations of HTT2800, we performed an Alamar blue assay (Invitrogen, Carlsbad, CA) according to the manufacturer's instructions. The cells were incubated for 4 days at $37^{\circ} \mathrm{C}$ in the culture medium, with various concentrations of HTT2800, in 96-well culture plates. The control cells were cultured in a dispersant medium containing $0.001 \%$ gelatin $(\mathrm{DM})$. Viable cells metabolized the dye. This resulted in an increase in fluorescence by excitation/emission at $550 \mathrm{~nm} / 600 \mathrm{~nm}$, recorded by a fluorescence multiplate reader (PowerScan 4, DS Pharma Biomedical, Osaka, Japan). Cell proliferation was calculated as follows: proliferation rate $=100 \times$ experimental value/each dispersant medium value. Test media were assayed six times.

\section{Observation of cells exposed to HTT2800}

THP-1 and MESO-1 cells were incubated for 4 days with $100 \mu \mathrm{g} / \mathrm{mL}$ and $10 \mu \mathrm{g} / \mathrm{mL}$ of HTT2800, respectively, and stained with $1 \mu \mathrm{g} / \mathrm{mL}$ of bisbenzimide $\mathrm{H} 33342$ fluorochrome trihydrochloride (H33342, Nacalai Tesque) for 30 minutes at $37^{\circ} \mathrm{C}$ in a $5 \% \mathrm{CO}_{2}$ incubator. The stained cells were observed through an Axio Observer Z1 fluorescence microscope (Zeiss, Jena, Germany) with excitation at $360 \mathrm{~nm}$. The cells were visualized by light or fluorescence microscopy using a $\times 40$ objective.

\section{Western blot analysis}

The cells were incubated with or without HTT2800 for 4 days in culture dishes $(\varnothing 6 \mathrm{~cm})$. After incubation, the cells were washed three times with $250 \mathrm{mM}$ saccharose in $10 \mathrm{mM}$ Tris- $\mathrm{HCl}(\mathrm{pH} 7.0)$ and solubilized in lysis solution containing $7 \mathrm{M}$ urea, $2 \mathrm{M}$ thiourea, 4\% CHAPS, 5\% $\beta$-mercaptoethanol, and $0.5 \%$ IPG buffer (pH 3-10, Bio-Rad, Irvine, CA). Cell lysates were centrifuged at $14,000 \times g$ for 5 minutes, and the protein in the supernatant was quantified using Coomassie Plus Assay Reagent (Thermo Scientific, Rockford, IL). The total protein solution was diluted 1:1 with Laemmli sample buffer (Bio-Rad) and boiled for 5 minutes. The proteins were then separated on $12.5 \%$ sodium dodecyl sulfate polyacrylamide electrophoresis gel (e-PAGEL, ATTO, Tokyo, Japan) and transferred onto a polyvinylidene fluoride membrane (Bio-Rad). The membrane was blocked with $\times 1$ nonprotein blocking agent (ATTO) in phosphate-buffered saline with $0.1 \%$ Tween 20 , for 30 minutes at room temperature, and probed with the primary rabbit antihuman DJ-1 antibody (sc-32874, Santa Cruz Biotechnology, Santa Cruz, CA) for 
one hour at room temperature. After washing, the membrane was incubated with the secondary antirabbit IgG, horseradish peroxidase-linked species-specific whole antibody from a donkey (GE Healthcare, Little Chalfont, UK) for one hour at room temperature, and then developed with ECLplus chemiluminescent detection reagent (GE Healthcare, Piscataway, NJ). The membrane was stripped with Restore Plus Western blot stripping buffer (Thermo Scientific), and detection was repeated using the primary monoclonal anti$\beta$-actin antibody (Sigma-Aldrich, St Louis, MO) and the antimouse IgG, horseradish peroxidase-linked species-specific whole antibody from sheep (GE Healthcare). The obtained bands were quantified by Quantity One software (Version 4, Bio-Rad). The expression of DJ-1 protein was represented as a percentage of dispersant medium, after correcting the value by the quantified $\beta$-actin.

\section{Immunocytochemistry}

The cells were incubated with or without HTT2800 for 4 days on culture chamber slide. After incubation, the cells were washed once with phosphate-buffered saline, blocked with $10 \%$ normal goat serum in phosphate-buffered saline for 30 minutes, and probed with the primary rabbit antihuman DJ-1 antibody overnight at $4^{\circ} \mathrm{C}$. After washing, the slides were incubated with the secondary antibody (Alexa Fluor ${ }^{\circledR}$ 594 goat antirabbit $\mathrm{IgG}$, Invitrogen) for one hour at room temperature, and then mounted with $90 \%$ glycerol containing $1 \mu \mathrm{g} / \mathrm{mL} \mathrm{H33342.} \mathrm{The} \mathrm{cells} \mathrm{were} \mathrm{visualized} \mathrm{using} \mathrm{an}$ LSM510 NLO laser-scanning confocal microscope (Zeiss) with a $\times 63$ objective.

\section{Isolation of total RNA and quantitative real-time polymerase chain reaction}

MESO-1 cells were washed three times with ice-cold phosphate-buffered saline. The cells were harvested in $500 \mu \mathrm{L}$ of TRIzol reagent (Invitrogen) and total RNA was extracted. One microgram of each total RNA preparation was then reverse transcribed using ReverTra Ace (Toyobo, Osaka, Japan) and 2.5 $\mu \mathrm{M}$ random primers. Quantification of mRNA levels was performed using the ABI Prism 7000 Sequence Detection System (Applied Biosystems, Foster City, CA) and the First Start Universal SYBR Green PCR Master Mixture (Roche Applied Science, Mannheim, Germany) with the following primer pair sets: DJ-1, QuantiTect ${ }^{\circledR}$ Primer Assay (Hs_PARK7_1_SG, Qiagen, Dusseldorf, Germany); and GAPDH 5'-CTGCACCACCAACTGCTTAG-3' (forward) and 5'-GGGCCATCCACAGTCTTCT-3' (reverse). The cycling parameters for these assays were: $50^{\circ} \mathrm{C}$ for 2 minutes, $95^{\circ} \mathrm{C}$ for 2 minutes, 40 cycles of $95^{\circ} \mathrm{C}$ for 30 seconds, and finally, $60^{\circ} \mathrm{C}$ for one minute. Quantitative results were obtained from the $C t$ values, which were the inverse ratios relative to the starting polymerase chain reaction product. The relative quantification was obtained by calculating $2^{-\Delta C t}$, where $\Delta C t=C t_{\text {target gene }}-C t_{\mathrm{GAPDH}}$. Quantification of the cDNA levels for each gene was performed using three replicates of each cDNA sample obtained.

\section{Statistical analysis}

Data are presented as the mean \pm standard error of the mean. The Student's $t$-test was applied, and $P<0.05$ was considered to be statistically significant.

\section{Results and discussion}

To identify potential biomarkers for MWCNTs in vitro, we used two different cell lines, ie, THP-1 and MESO-1. We recently reported that DJ-1 protein expression decreased when U937 cells were exposed to MWCNTs for 4 days; however, carbon black levels were not altered in response to DJ-1. ${ }^{20}$ Similar to U937 cells, THP-1 human acute monocytic leukemia cells have the ability to differentiate into macrophages. ${ }^{22}$ The objective of the present study was to confirm whether the expression of DJ-1 in U937 cells is universal. We recently also reported that exposure of BEAS-2B cells (derived from human bronchial epithelium) to HTT2800 proved cytotoxic, ${ }^{23}$ causing arrest of proliferation. One of the most significant differences between U937 and BEAS-2B cells is their surface adhesiveness. Therefore, in the present study, we used adherent MESO-1 cells (derived from human malignant pleural mesothelioma) to evaluate DJ-1 protein expression upon exposure to MWCNTs. Pulmonary mesothelial cells are thought to constitute the crucial cell type for asbestos toxicity.

The proliferation of THP-1 and MESO-1 cells exposed to HTT2800 for 4 days was clearly different (Figure 1A). While the propagation of MESO-1 cells was suppressed by HTT2800 in a concentration-dependent manner (with a few dead cells observed in the culture dish), THP-1 cells were not affected by the nanomaterial. Figure 1B depicts the cell images after 4 days of culture with or without HTT2800. In the case of MESO-1 cells, endocytosis of MWCNTs was clearly observed. These results were in accordance with a previous report, in which a similar effect was observed in the BEAS-2 cell line. ${ }^{23}$ By contrast, in the case of THP-1 cells, MWCNTs adhered around the cells, but were not ingested. This response was similar to that previously observed in U937 cells. ${ }^{19}$ 
Figure 2A shows the expression levels of DJ-1 protein, determined by means of Western blot analysis. In comparison with the vehicle control, the quantity of DJ-1 detected in THP-1 cells exposed to $100 \mu \mathrm{g} / \mathrm{mL}$ of HTT2800 was reduced to $67 \%$. This finding is in accordance with the results obtained with U937 cells exposed to MWCNTs for 4 days, analyzed using the proteomic approach. ${ }^{19}$ The decrease rate observed in the present study was lower than that previously documented, ${ }^{24}$ because our Western blot quantitative analysis was performed by summing oxidized and reduced DJ-1, whereas Duan et al separated the protein using two-dimensional electrophoresis. Correspondingly, in

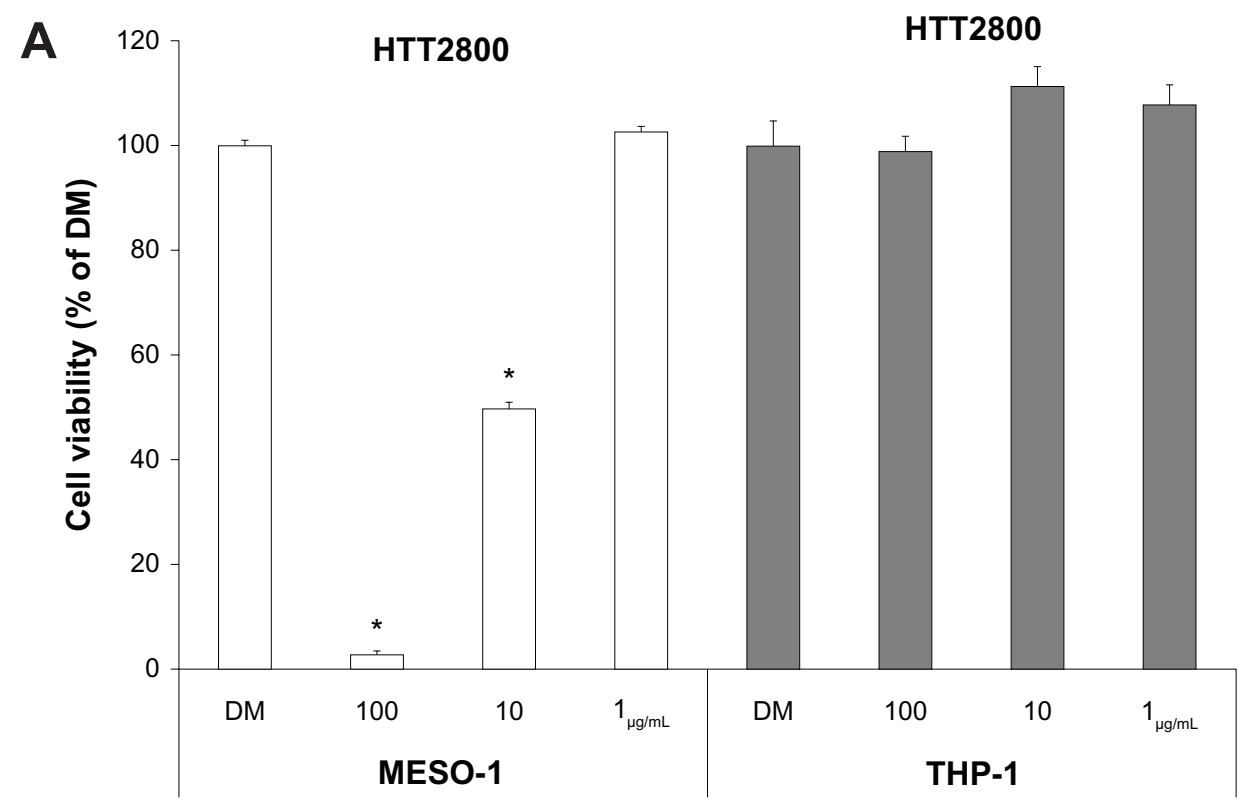

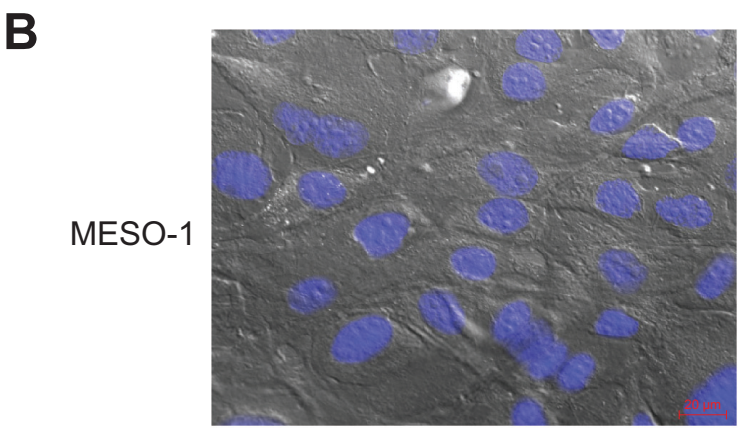

DM

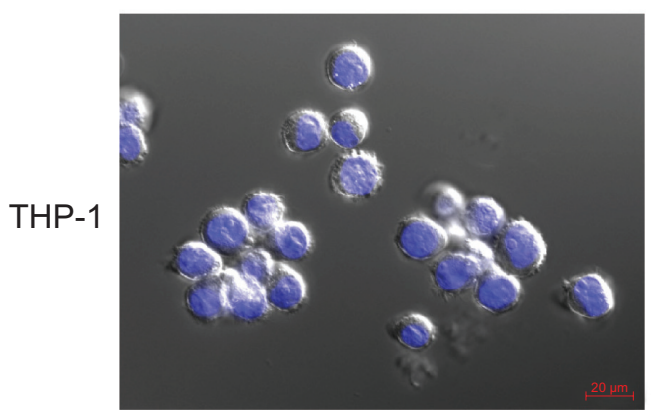

DM

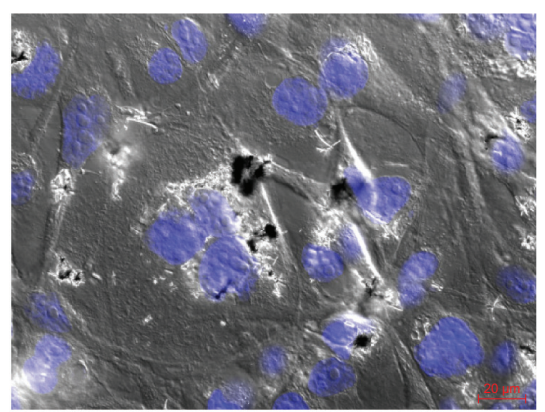

$10 \mu \mathrm{g} / \mathrm{mL}$ HTT2800

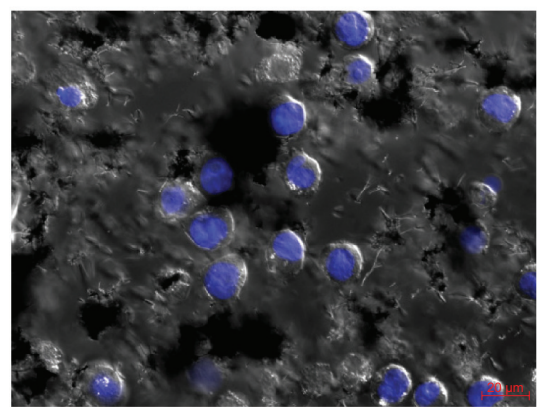

$100 \mu \mathrm{g} / \mathrm{mL}$ HTT2800

Figure I Influence of HTT2800 on cell viability. MESO-I and THP-I cells were exposed to varying concentrations of HTT2800 for 4 days. (A) Cell viability assessed by Alamar blue assay (B) Merged image of differential interference contrast and fluorescence in MESO-I and THP-I cells exposed to HTT2800 (nuclei were stained with $\mathrm{H} 33342$; bars in red indicate $20 \mu \mathrm{m}$ ).

Notes: Data are compared with dispersant medium, $\mathrm{n}=6$, mean \pm standard error of the mean, $* \mathrm{p}<0.00 \mathrm{I}$.

Abbreviation: DM, dispersant medium containing $0.001 \%$ gelatin. 
A

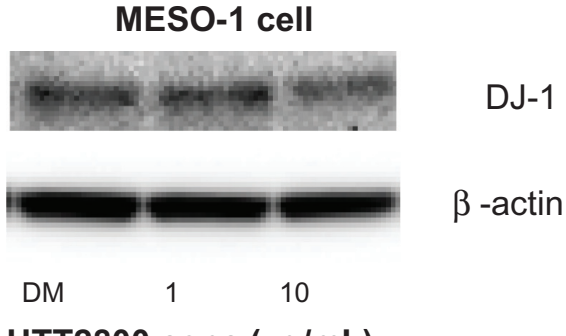

HTT2800 conc $(\mu \mathrm{g} / \mathrm{mL})$

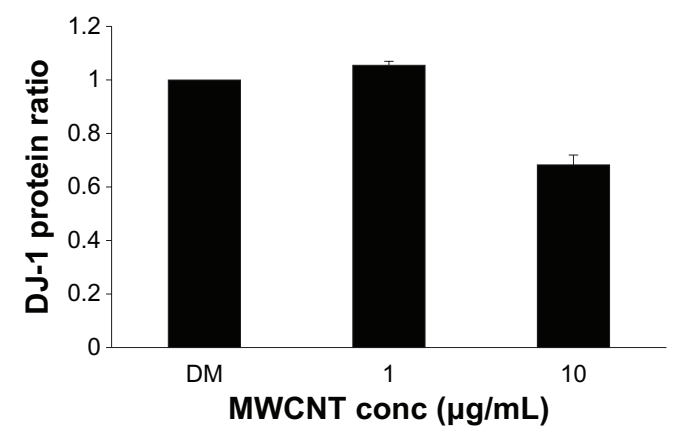

B

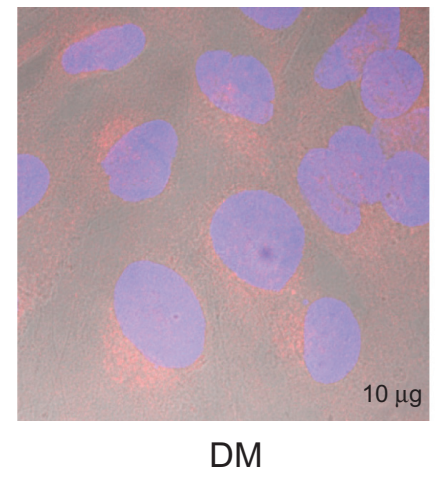

THP-1 cell

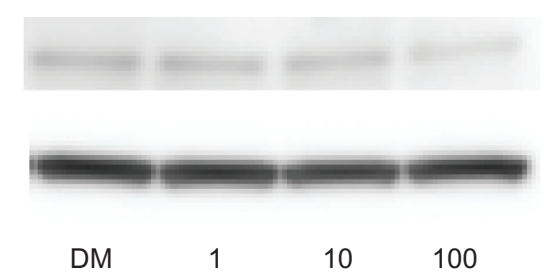

HTT2800 conc $(\mu \mathrm{g} / \mathrm{mL})$
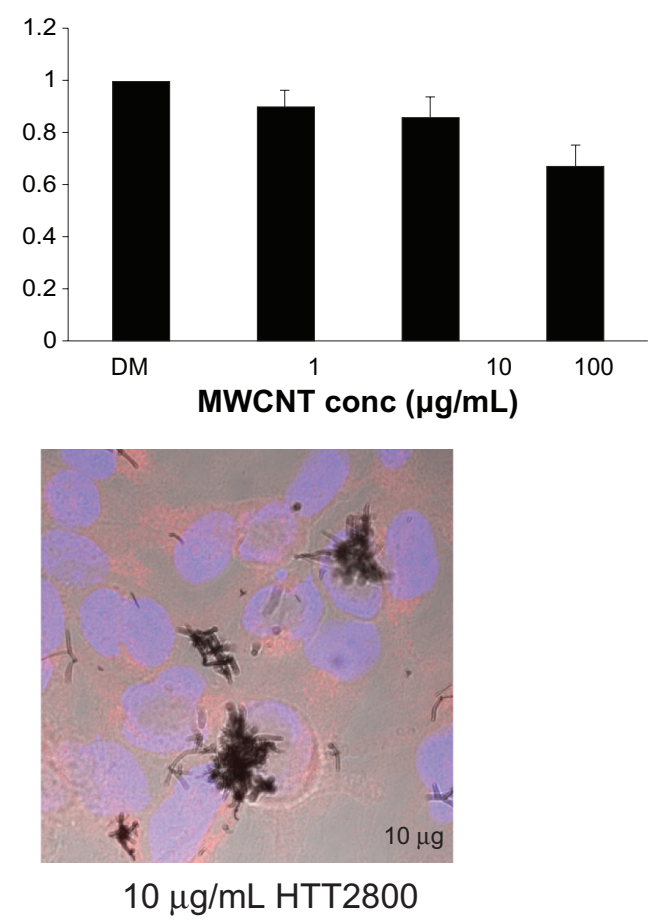

Figure 2 DJ-I protein expression after HTT2800 exposure. MESO-I and THP-I cells were exposed to varying concentrations of HTT2800 for 4 days. (A) Expression of DJ-I protein was normalized to $\beta$-actin and represented as the ratio compared with dispersant medium ( $n=4$, mean \pm standard error of the mean). (B) Cellular localization of DJ-I protein in MESO-I cells after exposure to $10 \mu \mathrm{g} / \mathrm{mL}$ of HTT2800 for 96 hours (DJ-I was stained with Alexa Fluor 594 and nuclei were stained with H33342).

Note: Bars in white indicate $10 \mu \mathrm{m}$.

Abbreviation: DM, dispersant medium containing $0.001 \%$ gelatin.

MESO-1 cells exposed to $10 \mu \mathrm{g} / \mathrm{mL}$ of HTT2800, DJ-1 expression was reduced to $68 \%$ compared with the vehicle control.

It has been reported that oxidative stress induces intracellular redistribution of DJ-1.25 Therefore, we performed immunofluorescence staining of DJ-1. However, we observed no changes in intracellular localization of the protein (Figure 2B).

We further investigated the expression of DJ-1 mRNA in MESO-1 cells by quantitative real-time polymerase chain reaction. MESO-1 cells are adherent and separation of the MWCNTs is easy. Thus, in comparison with cell lines characterized by nonadherent cells, MESO-1 cells are more advantageous when developing an evaluation method for highly biocompatible MWCNTs in vitro. The decrease in DJ-1 mRNA expression was time-dependent and statistically significant after day 2 (Figure 3). Our quantitative real-time polymerase chain reaction results indicate approximately $50 \%$ reduction in expression, which is larger than that observed in the case of Western blotting. However, this finding is in accordance with the decrease in DJ-1 expression previously demonstrated using the proteomic approach. ${ }^{19}$

Duan et al reported that total and reduced DJ-1 expression in human pneumocytes was decreased by hydrogen peroxide. ${ }^{24}$ Moreover, we recently demonstrated that purified MWCNTs tended to increase the production of intracellular hydrogen peroxide in human bronchial epithelial cells, one hour and 24 hours after exposure. This was accompanied by the accumulation of other intracellular reactive oxygen species after 24 hours (submitted for publication). MWCNT endocytosis does not occur as early as one hour after exposure. Nevertheless, augmentation of the intracellular 


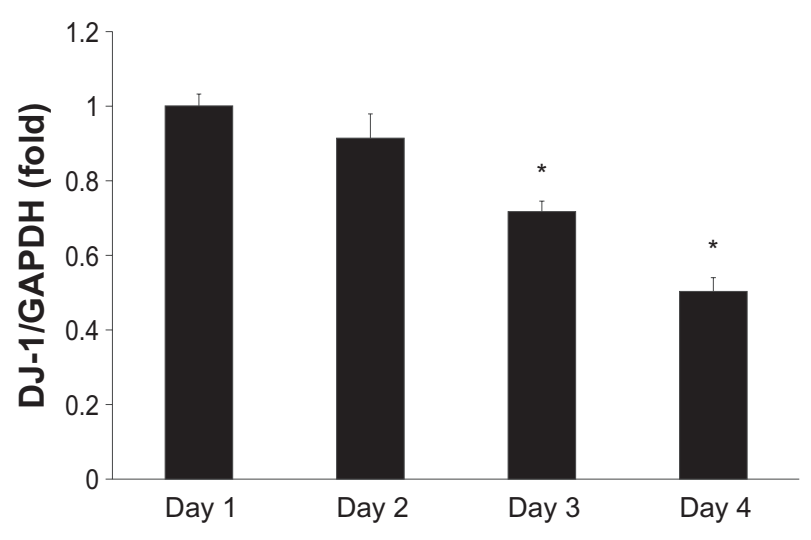

Figure 3 Time-course analysis of DJ-I mRNA expression. MESO-I cells were exposed to $10 \mu \mathrm{g} / \mathrm{mL}$ of HTT2800. RNA was isolated every day for 4 days; mRNA levels of $\mathrm{DJ}$-I were determined by quantitative real-time polymerase chain reaction and normalized to glyceraldehyde 3-phosphate dehydrogenase.

Notes: $\mathrm{n}=3$, mean \pm standard error of the mean, $* \mathrm{p}<0.01$.

hydrogen peroxide level at this time point may indicate the requirement for cells to come into contact with MWCNTs. In the present study, THP-1 cells only contacted MWCNTs, and did not endocytose them. Thus, the decrease in DJ-1 expression may have been caused by an intracellular hydrogen peroxide boost, generated by the contact between THP-1 cells and MWCNTs.

We evaluated the influence of other types of carbon nanomaterials on DJ-1 mRNA levels in MESO-1 cells (Figure 4). Cup-stacked carbon nanotubes did not change the expression level. By contrast, Sumi black increased it by 1.8 -fold. At a concentration of $10 \mu \mathrm{g} / \mathrm{mL}$, neither of the carbon nanomaterials showed cytotoxicity, but both were endocytosed (data not shown). Moreover, the pattern of cytokine secretion in THP-1 cells exposed to Sumi black differed from that

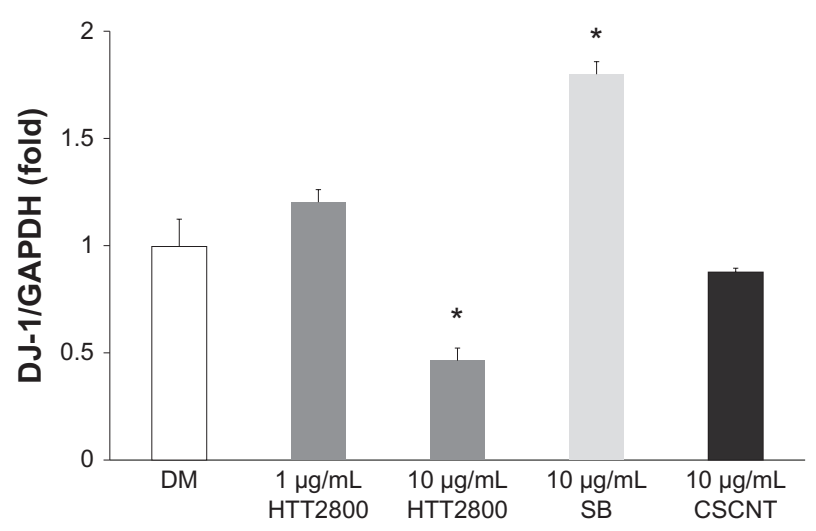

Figure 4 DJ-I mRNA expression after exposure to HTT2800, Sumi black, and cupstacked carbon nanotubes. MESO-I cells were exposed to diverse carbon nanomaterials for 4 days; $m R N A$ levels of $D J$-I were determined by quantitative real-time polymerase chain reaction and normalized to $\mathrm{G}$ glyceraldehyde 3-phosphate dehydrogenase.

Notes: $\mathrm{n}=3$, mean \pm standard error of the mean, $* \mathrm{p}<0.01$.

Abbreviations: DM, dispersant medium containing $0.001 \%$ gelatin; SB, Sumi black; CSCNT, cup-stacked carbon nanotubes. observed in THP-1 cells exposed to MWCNTs (submitted for publication). Our results indicate that different physical properties of the carbon nanomaterials used were recognized by the cell membrane, resulting in distinctive responses. Our previous finding that HTT2800 converted the differentiation pathway of $\mathrm{C} 2 \mathrm{C} 12$ myoblasts into that of adipoblast-like cells $^{26}$ further supports this hypothesis.

DJ-1 exists abundantly in the human body, with extremely diverse functions. However, it remains to be determined whether it has a tissue-specific or organ-specific role. We propose that, by measuring the expression of DJ-1 in blood cells, it may be possible to determine the extent of MWCNT exposure. In the present study, we observed a reduction in DJ-1 protein expression, regardless of the cytotoxic activity of intracellular HTT2800. Moreover, exposure to HTT2800, but not to Sumi black or cup-stacked carbon nanotubes, caused a reduction in DJ-1 mRNA levels. Thus, we conclude that DJ-1 is a novel biomarker for the development of biocompatible MWCNTs.

\section{Acknowledgments}

We thank the staff of the Division of Instrumental Analysis at the Research Center for Human and Environmental Sciences of Shinshu University for their help. This research was supported by the Program for Fostering Regional Innovation in Nagano, and a grant-in-aid (No. 19002007) from the Ministry of Education, Culture, Sports, Science, and Technology of Japan.

\section{Disclosure}

The authors report no conflicts of interest in this work.

\section{References}

1. Saito N, Usui Y, Aoki K, et al. Carbon nanotubes: biomaterial applications. Chem Soc Rev. 2009;38(7):1897-1903.

2. Endo M, Strano M, Ajayan P. Potential applications of carbon nanotubes. Carbon Nanotubes. 2008;111:13-61.

3. Endo M. Grow carbon fibers in the vapor phase. Chemtech. 1988;18(9): 568-576.

4. Donaldson K, Murphy FA, Duffin R, Poland CA. Asbestos, carbon nanotubes and the pleural mesothelium: a review of the hypothesis regarding the role of long fibre retention in the parietal pleura, inflammation and mesothelioma. Part Fibre Toxicol. 2010;7:5.

5. Jaurand MC, Renier A, Daubriac J. Mesothelioma: Do asbestos and carbon nanotubes pose the same health risk? Part Fibre Toxicol. 2009;6:16.

6. Pacurari M, Castranova V, Vallyathan V. Single- and multi-wall carbon nanotubes versus asbestos: are the carbon nanotubes a new health risk to humans? J Toxicol Environ Health A. 2010;73(5):378-395.

7. Poland CA, Duffin R, Kinloch I, et al. Carbon nanotubes introduced into the abdominal cavity of mice show asbestos-like pathogenicity in a pilot study. Nat Nanotechnol. 2008;3(7):423-428.

8. Muller J, Huaux F, Moreau N, et al. Respiratory toxicity of multi-wall carbon nanotubes. Toxicol Appl Pharmacol. 2005;207(3):221-231. 
9. Porter DW, Hubbs AF, Mercer RR, et al. Mouse pulmonary dose- and time course-responses induced by exposure to multi-walled carbon nanotubes. Toxicology. 2010;269(2-3):136-147.

10. Hirano S, Fujitani Y, Furuyama A, Kanno S. Uptake and cytotoxic effects of multi-walled carbon nanotubes in human bronchial epithelial cells. Toxicol Appl Pharmacol. 2010;249(1):8-15.

11. Magrez A, Kasas S, Salicio V, Pasquier N, Schwaller B, Forrò L. Cellular toxicity of carbon-based nanomaterials. Nano Lett. 2006;6(6): 1121-1125.

12. Muller J, Delos M, Panin N, Rabolli V, Huaux F, Lison D. Absence of carcinogenic response to multiwall carbon nanotubes in a 2-year bioassay in the peritoneal cavity of the rat. Toxicol Sci. 2009;110(2):442-448.

13. Taira T, Saito Y, Niki T, Iguchi-Ariga SM, Takahashi K, Ariga H. DJ-1 has a role in antioxidative stress to prevent cell death. EMBO Rep. 2004; 5(2):213-218.

14. Shendelman S, Jonason A, Martinat C, Leete T, Abeliovich A. DJ-1 is a redox-dependent molecular chaperone that inhibits alpha-synuclein aggregate formation. PLoS Biol. 2004;2(11):e362.

15. Junn E, Jang WH, Zhao X, Jeong BS, Mouradian MM. Mitochondrial localization of DJ-1 leads to enhanced neuroprotection. J Neurosci Res. 2009;87(1):123-129.

16. Le Naour F, Misek DE, Krause MC, et al. Proteomics-based identification of RS/DJ-1 as a novel circulating tumor antigen in breast cancer. Clin Cancer Res. 2001;7(11):3328-3335.

17. Clements CM, McNally RS, Conti BJ, Mak TW, Ting JP. DJ-1, a cancerand Parkinson's disease-associated protein, stabilizes the antioxidant transcriptional master regulator Nrf2. Proc Natl Acad Sci U SA. 2006; 103(41):15091-15096.
18. Bonifati V, Rizzu P, van Baren MJ, et al. Mutations in the DJ-1 gene associated with autosomal recessive early-onset parkinsonism. Science. 2003;299(5604):256-259.

19. Haniu H, Matsuda Y, Takeuchi K, Kim YA, Hayashi T, Endo M. Proteomics-based safety evaluation of multi-walled carbon nanotubes. Toxicol Appl Pharmacol. 2010;242(3):256-262.

20. Haniu H, Matsuda Y, Usui Y, et al. Toxicoproteomic evaluation of carbon nanomaterials in vitro. J Proteomics. March 23, 2011. [Epub ahead of print.]

21. Usami N, Fukui T, Kondo M, et al. Establishment and characterization of four malignant pleural mesothelioma cell lines from Japanese patients. Cancer Sci. 2006;97(5):387-394.

22. Drexler HG, Otsuka K, Gaedicke G, Minowada J. Changes in isoenzyme profiles during induction of differentiation in human myelomonocytic leukemia cell lines. Cancer Res. 1986;46(12 Pt 1):6078-6082.

23. Tsukahara T, Haniu H. Cellular cytotoxic response induced by highly purified multi-wall carbon nanotube in human lung cells. Mol Cell Biochem. 2011;352(1-2):57-63.

24. Duan X, Kelsen SG, Merali S. Proteomic analysis of oxidative stressresponsive proteins in human pneumocytes: insight into the regulation of DJ-1 expression. J Proteome Res. 2008;7(11):4955-4961.

25. Lev N, Ickowicz D, Melamed E, Offen D. Oxidative insults induce DJ-1 upregulation and redistribution: implications for neuroprotection. Neurotoxicology. 2008;29(3):397-405.

26. Tsukahara T, Haniu H. Nanoparticle-mediated intracellular lipid accumulation during $\mathrm{C} 2 \mathrm{C} 12$ cell differentiation. Biochem Biophys Res Commun. 2011;406:558-563.
International Journal of Nanomedicine

\section{Publish your work in this journal}

The International Journal of Nanomedicine is an international, peerreviewed journal focusing on the application of nanotechnology in diagnostics, therapeutics, and drug delivery systems throughout the biomedical field. This journal is indexed on PubMed Central,

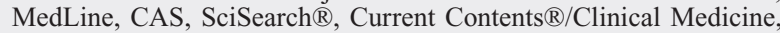

\section{Dovepress}

Journal Citation Reports/Science Edition, EMBase, Scopus and the Elsevier Bibliographic databases. The manuscript management system is completely online and includes a very quick and fair peer-review system, which is all easy to use. Visit http://www.dovepress.com/ testimonials.php to read real quotes from published authors. 